\title{
AKOMODASI BUDAYA SEBAGAI MODEL KEBERTERIMAAN KESENIAN BARONGSAI
}

\author{
Isa Ansari \\ i_ansori@yahoo.com
}

\begin{abstract}
The main objective of this research was to create a model of social integration in the performance of Barongsai Dance and to build understanding of multicultural awareness based on traditional arts. The target of this study was the formulation of a social integration model in the performance of Barongsai Dance. To achieve this goal, researchers used descriptive analytical methods. The data were obtained by conducting interviews, observation, documentation. The results of this researchhave formulated an accommodation model through an adaptation process. Adaptation that is done is in the attitude adaptation which is by strengthening the emotive and cognitive elements. The second is functional adaptation by adapting to ritual functions, entertainment functions, and sports and competition functions.
\end{abstract}

Keywords: Integration Model, BarongsaiDance, Acceptance

\section{PENDAHULUAN}

Pada konteks seni pertunjukan, keberagaman bukanlah hal asing, sebagaimana yang dikodifikasi oleh Nur Sahid (2000) dengan menerbitkan bunga rampai tentang keberagaman dalam seni pertunjukan teater. Beberapa penulis yang ada di dalam buku tersebut menggunakan istilah yang berbeda antara satu dengan lainnya, Bakdi Soemanto (2000) menggunakan istilah interkulturalisme untuk menjelaskan kontak budaya antara kesenian tradisi dengan bentuk pertunjukan dan budaya barat. Adapun Saini Kosim (2000) menggunakan istilah multikultur untuk menunjukkan kuatnya pengaruh budaya manca terhadap perkembangan teater di Indonesia.

Jejak keberagaman tersebut mempunyai sejarah panjang yang dapat dirunut sejak zaman prasejarah. Claire Holt (2000) dan Djakob Soemardjo (1992) menyebutkan kebudayaankebudayaan besar yang mempengaruhi seni pertunjukan di Indonesia yakni masa prasejarah,
Hindu, Budha, Islam, Cina, dan Kristen (Eropa). Kebudayaan-kebudayaan besar tersebut hadir dalam bentuk pertunjukan, properti, alur cerita, tokoh, ataupun nilai sebagai bentuk pembelajaran kepada masyarakat. Realitas historis tersebut menegaskan adanya kesadaran untuk mengakui dan mengapresiasi kebudayaan lain yang menyatu dalam seni pertunjukan.

Dalam konteks teater, masuknya unsurunsur manca ataupun kebudayaan lain dalam suatu bentuk seni pertunjukan, seperti pada seni pertunjukan ketoprak yang memasukkan unsur pertunjukan barat dalam bentuk pertunjukan tradisi Jawa, cenderung ditujukan untuk kebutuhan estetis. Berbeda halnya dengan wayang yang mempunyai kecenderungan diplomatis dan ideologis, terutama ketika idiom-idiom Islam hadir dalam bentuk dan lakon wayang. Karena adanya perpaduan dan kontak antar dua atau lebih kebudayaan pada seni pertunjukan tersebut, persepsi kita menyebutnya 
sebagai bentuk kesadaran multikultural dari masyarakat tradisi. Pandangan ini juga dikuatkan oleh Umar Kayam (1981: 66), bahwa teater tradisi dapat memperoleh masukan cita rasa ataupun konsepkonsep kebudayaan daerah lain. Bahkan, dalam proses 'Indonesianisasi' terbuka lebar bagi teater tradisi akan masuknya gagasan dan cita rasa negara lain yang bersifat multikultural.

Secara teoritik, Ricardo L. Garcia (1982:

37-42) menjelaskan bahwa pandangan multikulturalisme berangkat dari teori Cultural Pluralism: Mosaic Analogy, yang berpandangan bahwa masyarakat yang terdiri atas individu-individu yang beragam latar belakang agama, etnik, bahasa, dan budaya, memiliki hak untuk mengekspresikan identitas budayanya secara demokratis. Teori ini sama sekali tidak meminggirkan identitas budaya tertentu, termasuk identitas budaya kelompok minoritas sekalipun. Jika dalam suatu masyarakat terdapat individu berlatar belakang keyakindan dan budaya yang berbeda seperti Jawa, Sunda, Sumatra, Madura, Islam, Kristen, Hindu, Budha dan agama yang dilindungi secara hukum, masing-masing individu berhak menunjukkan identitas budayanya, bahkan boleh mengembangkannya. Hal ini berarti bahwa multikulturalisme mengakui hak individu untuk tetap mengekspresikan identitas budayanya sesuai dengan latar belakang masing-masing.

Terkait dengan hal tersebut, di Kota Solo terdapat kesenian yang diklaim sebagai bentuk seni pertunjukan yang menghargai perbedaan bahkan dianggap sebagai bentuk pertunjukan multikultural yakni kesenian Barongsai. Secara umum unsur multikultural yang dilihat dari pertunjukan tersebut adalah pada keterlibatan masyarakat dari kelompok sukubangsa lain, yakni orang Jawa yang sebagian besar adalah kalangan pemuda. Selain juga dilihat dari keterlibatan masyarakat dari beragaman kelompok sukubangsa yang ada di kota Solo untuk menyaksikan pertunjukan tersebut.

Kehadiran masyarakat dari kelompok sukubangsa yang lain ini menjadi penting dalam pertunjukan Barongsai, karena Kota Solo pernah mengalami masa kelam terkait dengan interaksi antar kelompok suku bangsa pada tahun 1998 yang kemudian berulang pada tahun 2000 walaupun dalam skala yang kecil. Berbagai upaya dilakukan pada saat itu agar kelompok sukubangsa dan etnis yang berkonflik dapat membaur dan bekerjasama (Jamu'in, 2000). Oleh sebab itu, kehadiran seni pertunjukan Barongsai yang dipentaskan secara rutin pada setiap perayaan tahun Baru Cina (Imlek) dan dapat diterima oleh masyarakat Jawa, bahkan pelakunya juga dari masyarakat Jawa menjadi hal penting dalam konteks tersebut.

Penelitian ini dilakukan dengan melihat pada titik mana keberterimaan masyarakat dari kedua kelompok sukubangsa tersebut terhadap kesenian barongsai dan pelaku yang terlibat di dalamnya. Penelitian ini tidak dimaksudkan untuk mengungkit kembalipersoalan lama yang dialami oleh kelompok suku bangsa yang ada di Solo, namun lebih difokukskan pada proses integrasi yang terjadi terutama pada kesenian Barongsai untuk lebih memperkuat implementasi kebersamaan dalam perbedaan. Tulisan ini bermaksud untuk mendeskripsikan model integrasi sosial dalam seni pertunjukan barongsai, diharapkan dapat diterapkan pada kesenian lainnya dan relitas sosial-masyarkat.

\section{PEMBAHASAN}

\section{a. Model Akomodasi budaya pada seni pertunjukan Liong dan Barongsai}

Akomodasi merupakan suatu proses keberterimaan suatu budaya terhadap budaya lain dengan tetap mempertahankan unsur-unsur utama dari kebudayaan asal, sehingga terbentuk hubungan yang seimbang dalam hubungan-hubungan sosial antar individu dan kelompok-kelompok sehubungan dengan norma-norma dan nilai-nilai yang berlaku di masyarakat. Menurut Alo Liliweri (2005:139), bahwa secara sosiologis akomodasi mengandung aspek "keadaan" dan aspek "proses". Akomodasi sebagai aspek keadaan menunjukkan keadaan hubungan antar etnik atau antar ras yang seimbang, karena pihak-pihak yang melakukan akomodasi tersebut tetap menjaga nilai dan norma sosial yang berlaku umum dalam suatu masyarakat. Pada aspek proses, hubungan sosial antar etnik, antar ras, ataupun antar agama kerangka akomodasi ini dilakukan melalui proses adaptasi antara dua budaya atau lebih.

Dalam proses akomodasi tersebut, dialog atau diskusi secara terbuka menjadi prasyarat 
utama. Pihak-pihak yang berkonflik atau mengalami ketegangan sosial harus membuka diri untuk dapat berdialog secara terbuka. Dari proses tersebut, maka akomodasi merupakan suatu cara menyelesaikan pertentangan tanpa menghancurkan pihak lawan sehingga lawan tidak kehilangan kepribadiannya. Secara teoritik akomodasi sebagai upaya untuk menyelesaikan konflik terdapat beberapa bentuk yakni: pertama adalah coercion (koersi) yang dilakukan karena adanya paksaan.

Kedua, adalah compromise (kompromi) yakni pihak-pihak yang terlibat masing-masing mengurangi tuntutannya agar dicapai suatu penyelesaian terhadap suatu konflik yang terjadi. Ketiga, arbitration (arbitrasi) cara yang dilakukan adalah dengan meminta bantuan pihak ketiga yang dipilih oleh kedua belah pihak atau oleh badan yang kedudukannya lebih tinggi dari pihak-pihak yang bertikai. Keempat, mediation(mediasi) cara menyelesaikan konflik dengan jalan meminta bantuan pihak ketiga yang netral. Kelima adalah conciliation(konsiliasi) yakni suatu usaha mempertemukan keinginan-keinginan pihak-pihak yang bertikai untuk mencapai persetujuan bersama.

Keenam adalah toleration (toleransi) yang terkadang dinamakan toleran-participation yaitu suatu bentuk akomodasi tanpa adanya persetujuan formal. Ketujuh, Statlemate yakni suatu bentuk akomodasi dimana pihak-pihak yang bertikai atau berkonflik karena kekuatannya seimbang kemudian berhenti pada suatu titik tertentu untuk tidak melakukan pertentangan. Kedelapan, adjudication (ajudikasi) yakni suatu bentuk penyelesaian konflik melalui pengadilan. Kesembilan adalah segregation (segregasi) yakni upaya penyelesaian sengketa dengan cara masing-masing pihak saling menghindari konflik agar tidak berkelanjutan. Kesepuluh adalah elimination (eliminasi) yang merupakan suatu upaya penyelesaian sengketa karena salah satu pihak bersedia mengalah, meminta maaf atau mengundurkan diri dari persaingan.

Pada konteks seni pertunjukan barongsai dan liong yang ada di Kota Solo, akomodasi yang terjadi cenderung pada bentuk kompromi dan toleransi, keterlibatan masyarakat yang berbeda baik dari segi suku bangsa ataupun agama di organisasi kesenian tersebut lebih didasarkan pada proses tawar-menawar (negosiasi) baik secara psikologis individu ataupun sosio-kultural. Orang Jawa yang terlibat di dalam kelompok barongsai dan liong tersebut tidak pernah dipaksa untuk mengikuti ritual atau dituntut untuk melaksanakan kebudayaan Cina peranakan, atau sebaliknya orang Cina peranakan juga tidak pernah dituntut untuk mengikuti kebudayaan anggota lain yang terlibat di dalam kesenian tersebut. Bahkan yang terjadi sebaliknya mereka diberi kebebasan untuk memahami dan menjalankan kebudayaan yang mereka anut.

Kehadiran masyarakat dari etnis atau agama lain dalam ritual yang dilakukan hanya sebatas suatu proses dalam berkesenian. Selain itu kehadiran mereka (sukubangsa Jawa) pada saat ritual dilangsungkan, tidak ada keharusan bahwa mereka harus terlibat dalam ritual, karena dari beberapa informasi yang didapatkan, kehadiran anggota dari etnis Jawa tidak masuk kedalam vihara atau klenteng, tetapi mereka berada di luar, hanya pemain dari kalangan Tionghoa yang masuk dan terlibat dalam upacara. Sikap untuk dapat melaksanakan compromise ialah sikap untuk bersedia merasakan dan mengerti keadaan pihak lain. Hal inilah yang rasakan oleh anggota kelompok dari etnis atau agama lain mereka memahami dan mengerti akan exsistensi kesenian barongsai dan liong di kota Surakarta.

Selain cenderung pada bentuk kompromi, kesenian barongsai dan liong juga cenderung pada bentuk toleration (toleransi) yang terkadang dinamakan toleran-participation yaitu suatu bentuk akomodasi tanpa adanya persetujuan formal. Akomodasi dalam bentuk toleransi ini memerlukan kesadaran beberapa orang atau kelompok akan adanya pihak lain dalam rangka menghindari pertikaian. Karena proses negosiasi kultural tersebut terjadi dalam ruang ide dan dalam interaksi sosial antara anggota kelompok, sehingga tidak ada persetujuan formal di dalam kelompok tersebut terkait dengan realitas kebudayaan dan agama lain yang berkembang di anut oleh anggota kelompok kesenian tersebut.

Dalam proses akomodasi, dua etnik atau lebih yang terlibat konflik harus sepakat menerima perbedaan budaya, dan perubahan penerimaan itu harus melalui penyatuan penciptaan kepentingan 
bersama. Dengan proses tersebut orang-orang yang berbeda suku bangsa, etnik dan agama dapat mengakui perbedaan tersebut dalam lingkup masyarakat yang sama ataupun masyarakat yang lebih luas. Pandangan seperti inilah yang dikembangkan dalam proses akomodasi terhadap perbedaan yang menjadi realitas faktual pada kelompok barongsai dan liong. Kepentingan yang mereka ciptakan bersama adalah kepentingan estetis untuk sama-sama mencapai puncak keindahan dalam setiap pertunjukan yang mereka pergelarkan.

Kedua bentuk akomodasi yang ada di dalam kesenian barongsai tidak terlepas dari kemampuan anggota kelompok untuk beradaptasi dengan budaya dan keyakinan yang dikembangkan di kelompok barongsai yang nota bene merupakan kesenian tradisi masyarakat Tionghoa yang bersumber dari Tiongkok. Terutama yang dilakukan oleh anggota kelompok yang beretnis Jawa atau yang beragama Islam. Secara teoritik adaptasi merupakan suatu proses penyesuaian diri baik pada tataran nilai, norma, tingkah laku, ataupun ide dengan lingkungan baru yang ditempati. Nilai dan normanorma lama mencoba untuk diakomodasi dengan apa yang datang kemudian untuk dijadikan bagian dari nilai atau norma yang telah ada (Kaplan \& Manners, 200:112-113). Proses ini tentu bukan lah proses yang instan, namun merupakan suatu ancangan yang telah berlangsung lama. Menurut Alo Liliweri, dalam proses adaptasi tersebut terjadi dalam dua kontak yakni kontak pertama dan kontak lanjutan.

Pada saat terjadi kontak pertama, cenderung mengarah pada terjadinya konflik. Karena pada saat kontrak pertama ini berlangsung terjadi tarik ulur karena adanya perbedaan latar belakang etnis, ras, suku, ataupun agama. Kedua, terjadinya simbiosis egaliter dengan ras atau etnik. Perilaku yang kedua ini muncul karena terjadinya pencapaian kesepakatan koeksistensi dengan adanya pemerataan untuk mencapai keadilan. Ketiga, penyusunan sistem stratifikasi dan hierarki dengan terbentuknya kesepakatan-kesepakatan karena dilakukannya perundingan-perundingan antara kaum pendatangan dan penduduk setempat (Liliweri, 2005:140-142).

Kontak lanjutan adalah proses adaptasi yang lebih meningkat dari kontak pertama. Kontak lanjutan tersebut merupakan upaya lanjut yang dilakukan baik yang berhubungan dengan perilakuperilaku pertama, kedua ataupun ketiga pada saat terjadinya kontak pertama. Pada kontak lanjutan ini terjadi perkembangn sesuai dengan kesepakatan ataupun keinginan pihak dominan. Pada tahap inilah akomodasi tersebut dapat dilakukan karena tarik ulur dan perhitungan baik buruk telah terseleksi secara mekanik ataupun alamiah karena pengalaman dari kontak sosial yang telah dilakukan.

Pada konteks masyarakat Cina peranakan di kota Solo, kontak pertama telah berulang kali terjadi, terutama terkait dengan perilaku-perilaku yang mengarah pada konflik. Sebagaimana yang telah penulis sampaikan pada bahasan terdahulu. Kontak lanjutan yang mengarah pada pencarian bentuk-bentuk negosiasi sebagai suatu proses adaptasi yang dilakukan baik dari masyarakat tempatan (Jawa) ke masyarakat Cina peranakan, ataupun dari masyarakat Cina peranakan ke masyarakat tempatan. Berangkat dari pemahaman tersebut, maka penulis mendudukkan kesenian barongsai dan liong sebagai upaya bersama untuk membangun keberterimaan orang Cina peranakan dalam kehidupan masyarakat Jawa, ataupun sebaliknya. Hal inilah yang dilihat sebagai bentuk adaptasi yang dilakukan untuk menghilangkan eksklusifitas dari salah satu etnik di Kota Solo.

Dari penjelasan singkat tersebut, dapat dirumuskan beberapa tujuan dari akomodasi. Pertama, bahwa akomodasi ditujukan untuk mengurangi pertentangan antara orang per orang atau kelompok-kelompok manusia akibat perbedaan paham. Kedua, mencegah meledaknya pertentangan untuk sementara waktu. Ketiga adalah untuk memungkinkan terjadinya kerja sama antara kelompok satu dengan lainnya yang hidupnya terpisah karena budaya. Keempat adalah untuk melebur kelompok sosial yang terpisah.

Proses adaptasi antar anggota kelompok kesenian barongsai dan liong, dapat dilihat pada tiga bentuk, yakni adaptasi sikap yang terkait dengan kognitif dan knowladge para anggota kesenian barongsai. kedua adalah adaptasi fungsi yang dilakukan oleh anggota dari etnis Jawa. Keduabentuk akomodasi tersebut dapat juga 
dikatakan sebagai pentahapan dalam proses akomodasi budaya dalam kesenian barongsai. Kedua bentuk dari akomodasi budaya tersebut dijelaskan secara rinci dibawah ini.

\section{B. Adaptasi sikap}

Sikap yang dimaksud disini adalah persepsi individu ataupun kelompok etnis dan agama yang terlibat dalam kelompok-kelompok barongsai. Kesalahan persepsi yang didominasi oleh persepsi negatif terhadap etnis atau agama lain akan memunculkan perilaku dan tindakan-tindakan yang negatifjuga. Oleh karenanya perlu untuk memupuk persepsi positif terhadap kelompok dari etnis atau agama yang berbeda. Untuk menjelaskan model adapasi sikap ini, peneliti berangkat dari perubahan dan adaptasi emotif dan kognitif daripemain ataupun anggota keompok batrongsai. Karena dengan adanya perubahn positifterhadap emotif dan kognitif tentu akan memunculkan adaptasi sikap yang positif terhadap etnis atau agama lain.

Pertama adalah adaptasi emotif. Adaptasi emotif terkait dengan membangun perasaanperasaan positif terhadap produksi estetis dari kelompok etnis lain, dalam hal ini adalah kesenian barongsai yang merupakan produksi estetis masyarakat Tionghoa. Masa-masa awal berdirinya kelompok kesenian Tripusaka, terutama terkait dengan kesenian Liong dan Barongsai, masyarakat diluar etnis Tionghoa menilai bentuk kesenian tersebut sebagai propaganda budaya untuk memperkuat eksistensi masyarakat Tionghoa di Kota Solo. Hal ini tidak terlepas dari pandangan historis masyarakat Jawa terhadap etnis Tionghoa yang dianggap dekat dengan Partai Komunis Indonesia, sehingga stereotip negatif selalu dilekatkan pada mereka. Selain itu juga belum adanya keberterimaan secara utuh dari masyarakat di luar etnis Tionghoa terhadap budaya Tionghoa. Oleh karenanya pada-masa-masa awal berkembangnya kesenian barongsai yakni pasca 1998, masyarakat umum masih menganggap bahwa kesenian tersebut bukan untuk konsumsi publik, terutama adalah para pemainnya. Pandangan-pandangan negatif dan diskriminatif terhadap etnis Tionghoa inilah yang harus didekonstruksi untuk menumbuhkan pandangan-pandangan positif, kekeluargaan, dan humanistik terhadap etnis Tionghoa (wawancara dengan Yudi Jaelani, 3 september 2017)

Adaptasi emotif ini merupakan daya atau kekuatan emosional yang bersifat inklusif dan terlibat secara aktif dengan budaya dominan atau sebaliknya. Adaptasi emotif ini merupakan pengalaman subyektif yang diambil dari berbagai keterlibatan, pemahaman, dan kelangsungan fenomenologisnya dalam realitas nyata. Meminjam istilah dari Clifford Geertz bahwa adaptasi emotif ini dapat kita sejajarkan pemahamannya dengar "rasa". Menurut Geertz (1991:60), rasa mempunyai dua arti, pertama adalah rasa sebagai perasaan (feeling) dan rasa sebagai makna (meaning). Rasa sebagai feeling, merupakan salah satu dari panca indra orang Jawa yang terbagi kedalam pencecapan cira-rasa pada lidah, sentuhan pada badan, dan emosional yang berada di dalam hati, seperti rasa sedih dan rasa bahagia. Kedua adalah rasa sebagai makna (meaning) yang diterapkan dalam kata-kata yang dapat dijumpai pada buku, surat, puisi, atau bahkan dalam percakapan kita sehari-hari yang menunjukkan ketidaklangsungan dari kiasan-kiasan sebagai bentuk komunikasi dan hubungan sosial orang Jawa. Rasa juga dapat diwujudkan dalam tingkah laku untuk menunjukkan muatan implisit "perasaan" konotatif dari gerakan tari, gerak-gerak tata krama dan lain sebagainya.

Dengan pemahaman yang disejajarkan dengan konsep rasa dari clifford Geertz tersebut. Maka adaptasi emotif ini menjadi pintu masuk (entry point) pandangan-pandangan kemajemukan dan keberterimaan terhadap perbedaan, karena persoalan rasa tidak memandang perbedaan etnis, agama, golongan, ataupun status sosial, namun pemahaman rasa ini didasarkan pada pengalaman ketubuhan dan kognitifyang terlibat secara langsung dengan proses sosial yang terjadi. Dalam hal ini adalah kelompok kesenian liong dan barongsai dari Yayayan Tripusaka.

Menurut Adjie Chandra, perubahan emotif ini dibangun melalui keterbukaan dari setiap anggota yang tergabung dalam kelompok barongsai tersebut. Pertama, Tidak ada perlakuan khusus terhadap anggota dari kelompok etnis tertentu dan tidak ada eksklusifitas yang diberikan kepada orang tertentu 
dan kelompok etnis tertentu. Semua anggota mempunyai kesempatan yang sama untuk diajak pentas atau memainkan barongsai dan liong. Selain itu dalam kesenian barongsai ditanamkan rasa saling mempercayai antara satu tim, dapat dibayangkan hal yang akan terjadi jika tidak adanya saling mempercayai, maka sangat dimungkinkan pertunjukan yang dilakukan tidak akan berhasil. Anggota kelompok ini juga dibangun rasa tolong menolong dan kepedulian terhadap sesama, sehingga aktifitas kesenian yang mereka lakukan tidak hanya terkait dengan skill dan estetika, namun juga penanaman sifat-sifat positif kepada semuan anggota.

Bagi orang Tionghoa sendiri, adaptasi emotif yang mereka lakukan adalah mengembangkan sikap keterbukaan terhadap masyarakat lain untuk mempelajari dan memainkan kesenian barongsai beserta hal-hal yang terkait dengannya. Mereka harus dapat berbagi ruang dalam tradisi/kesenian yang mereka miliki. Dengan cara seperti ini terbangun sikap inklusif terhadap budaya lain. Selain itu adaptasi emotif yang juga mereka lakukan adalah bahwa mereka adalah bagian dari Jawa, sehingga terbangun pandangan-pandangan positif mereka terhadap orang Jawa yang terlibat dalam kesenian tersebut, umumnya adalah budaya Jawa secara luas.

Kedua adalah perubahan kognitif yang terkait dengan pengetahuan mereka terhadap identitas budayanya (self cultural identity) sehingga mereka dapat membandingkan dengan identitas lainnya. Dan juga pemahaman terhadap identitas budaya masyarakat lain, sehingga mereka dapat mendialogkan dan menegosiasikan makna-makna simbolik yang hadir dalam realitas keseharian mereka. Pemahaman terhadap identitas budayanya sendiri tidak selalu memunculkan pemahaman yang eksklusif terhadap budaya si pelaku, namun sebaliknya juga dapat memunculkan inklusifitas terhadap budaya ataupun identitas lain. Kevin misalnya yang merupakan siswa sekolah menengah atas di salah satu sekolah atas di Solo mencontohkan bahwa dia mempunyai pemahaman yang lebih dari teman-temannya sesama orang Tionghoa, terkait dengan budaya dan ajaran Konghucu. Pengetahuannya terhadap budaya dan ajaran Konghucu tersebut membuat dia merasa nyaman dan bebas untuk berteman, dan bertemua orang lain. Karena ajaran Konghucu mengajarkan kita untuk berbuat baik, dan bertingkah laku soopan terhadap orang tua dan orang yang lebih tua darinya.

Adaptasi kognitif ini dilakukan dalam bentuk pemahaman-pemahaman filosofis terhadap kesenian barongsai, seperti yang diungkapkan oleh Adjie Tjandra bahwa bermain liong barongsai bukan sekedar liukan tubuh biasa. Di dalam seni tersebut mengandung banyak nilai-nilai kehidupan yang diaplikasikan dalam komunitas. Liong barongsai adalah simbol keseimbangan dalam elemenelemennya yang harus diwujudkan dalam bentuk nyata terutama antar sesama anggota kelompok baringsai Tripusaka (wawancara, Adji Tjandara, 3 Agustus, 2017). Pemahaman para pemain dari masyarakat Jawa memahami makna dan nilai yang ditanamkan dalam pertunjukan barongsai secara kognitifmereka bandingkan dengan nilai dan makna dalam seni pertunjukan orang Jawa, terutama adalah wayang yang pada dasarnya juga mempunyai nilai religiusitas dan nilai hiburan (wawancara, Bayu jatmiko, 9 Agustus 2017). Di sini kita memahami bahwa pembandingan yang dilakukan tidak untuk merendahkan salah satunya, namun lebih pada pemupuk pemahaman dan pandangan-pandangan positif terhadap kesenian barongsai.

Adaptasi kognitif dari para pemain baik yang beretnis Tionghoa ataupun bersukubangsa Jawa yang didukung dengan perubahan afektif dan perilaku tersebut mengarah pada pencapain estetis dari setiap pemain yakni munculnya rasa suka dan senang dalam berkesenian. Karena dengan adanya adaptasi kognitif tersebut, mereka dapat mendialogkan antara pertunjukan dengan pengetahuan yang mereka miliki, sehingga mereka dapat memberikan makna dan menikmati pertunjukan yang sedang mereka lakukan. Hal ini tentunya dapat membuka sekat-sekat budaya (cultural barrier) dan agama yang berbeda. Karena selama ini perbedaan tersebut selalu didudukkan pada dua kutub yang dikotomis dan diperkuat dengan sentimen-sentimen budaya ataupun agama oleh para pendukung kebudayaanya. Capaian estetis mendialogkan hal tersebut dalam ruang kognitifyang teraplikasikan dalam tingkah laku para pendukungnya. Pada ruang sosial, sekat-sekat 
budaya juga diruntuhkan dengan meleburnya penonton dari berbagai agama, dan budaya. Karena kehadiran pemain dari sukubangsa Jawa menjadi gaya tarik sendiri bagi masyarakat untuk menyaksikan pertunjukan tersebut.

Pada konteks estetik adaptasi sikap secara positif ini membangun kesamaan kepentingan yakni keindahan, hal ini yang ditanamkan oleh pimpinan kelompok barongsai Tripusaka, bapak Adjie Tjandra. Menurutnya, bahwa kekayaan budaya tersebut merupakan sesuatu yang indah, oleh karena itu siapapun yang memainkan kekayaan budaya tersebut (seni tradisi) akan melahirkan keindahan. karena keindahan bukan hanya milik satu etnis atau kelompok tertentu, walaupun bentuk kesenian tersebut berbasis pada etnik tertentu. Seperti halnya kesenian barongsai yang nota bene merupakan kesenian tradisional masyarakat Tionghoa, hal ini tidak berarti bahwa keindahan seni pertunjukan tersebut akan muncul jika hanya dimainkan oleh orang Tionghoa, namun sebaliknya, justru dengan keterlibatan kelompok dari etnis lain akan membentuk keindahan dan gaya tariknya sendiri sehingga dapat diterima oleh masyarakat luas.

Paparan mengenai adaptasi sikap yang dilakukan baik oleh pemain beretnis Tionghoa ataupun pemain non-Tionghoa menegaskan kuatnya upaya membangun integrasi dalam dimensi kognitif, atau hubungan yang lebih 'rasional'. Kuatnya peran tokoh-tokoh Tionghoa dalam memberikan pemahaman mengenai kesenian Barongsai dan Liong terbukti mampu mengintegrasikan suku Tionghoa-Jawa di antara pemain. Oleh karena itu, potensi ini perlu diarahkan untuk memperkuat tumbuhnya upaya membangun hubungan yang lebih harmonis dengan cara menguatkan filosofi 'membangun pagar mangkok, daripada pagar tembok' (menguatkan modal sosial yang menguatkan integrasi sosial yang lebih harmonis dengan lingkungan sekitar). Upaya demikian yang lebih potensial menguatkan tumbuhnya simpati yang kian mengokohkan integrasi yang ada ke arah yang lebih alami atau wajar.

\section{Adaptasi Fungsi}

Adaptasi fungsi yang dimaksud disini adalah suatu upaya yang dilakukan oleh anggota barongsai untuk menyesuaikan secara psikologis dan fisiologis terhadap kesenian tersebut baik dalam bentuk nilai, norma, tingkah laku ataupun ide. Pada konteks fungsi, penyesuaian yang mereka lakukan baik oleh anggota kelompok non Tionghoa ataupun anggota kelompok dari kalangan Tionghoa adalah dengan melakukan negosiasi ide dan nilai terhadap kesenian tersebut. Bagi pemain atau anggota kelompok kesenian barongsai yang non-Tionghoa, negosiasi sebagai bentuk adaptasi tersebut menjadikan mereka sebagai “orang Jawa yang Nyinani” (Jawa yang menjadiCina), kebalikan dari proses awal yang berlangsung yakni "Cina yang njawani”" (orang Cina yang menjadi Jawa). "Jawa yang Nyinani" ini memang hanya berlangsung pada kondisi-kondisi tertentu, terutama keterlibatan mereka dalam kesenian Liong dan Barongsai. Mereka menggunakan kostum dan segala atribut orang Tionghoa. Inilah yang mencerminkan bahwa mereka merupakan orang "Jawa yang Nyinani" (Sudono.dkk,2013:228-229).

Kajian mengenai fungsi barongsai ini pada dasarnya sudah dilakukan secara akademik, seperti laporan tugas akhir yang berjudul peran seni pertunjukan barongsai dalam pengembangan wisata budaya di kota Surakarta yang ditulis oleh Diah Ayuk Kusumaningtyas (2009), Mahasiswa Universitas Negeri Sebelas Maret. Penjelasan-penjelasan mengenai fungsi barongsai tersebut banyak menggunakan informasi dari Diyah Ayuk. Hal ini dikarenakan beberapa informasi yang penulis dapatkan juga sama dengan informasi yang dikemukakan oleh Diyah Ayuk.

\section{Fungsi ritual}

Fungsi ritual adalah fungsi awal hadirnya kesenian tersebut sebagaimana informasi sejarah kesenian ini yang telah disampaikan pada pembahasan terdahulu. Barongsai dan liong sebagai bentuk ritual menjadi keyakinan yang terus dipertahakan oleh masyarakat Tionghoa dimanapun mereka berada terutama untuk menghormati ajaran leluhur atau nenek moyang mereka. Pertunjukan barongsai sebagai kebutuhan ritual, biasanya ditampilkan pada hari raya keagamaan Khonghucu, seperti tahun baru China/ Imlek, Cap Go Meh, Tiong 
Chiu atau hari kelahiran Nabi Khongcu ( 27 bulan 8 Imlek, yang biasanya jatuh sekitar bulan September / Oktober). Pada perayaan hari-hari besar tersebut kesenian ini diarak di sepanjang jalan dengan maksud agar keselamatan, kebahagiaan dapat menyebar sesuai dengan tempat-tempat yang di lewati.

Masyarakat Tionghoa meyakini bahwa kesenian tersebut mampu menghalau segala unsur jahat dan negatif di sepanjang jalan yang dilewati, sehingga akan membawa kedamaian dan kesejahteraan bagi yang melihatnya. Pementasan barongsai dalam kegiatan ritual biasanya terdapat 3 sesi. Pada sesi pertama adalah upacara sembahyangan. Barongsai disembahyangkan terlebih dahulu sebelum nantinya akan diarak berkeliling kota. Upacara sembahyangan atau pensucian barongsai ini dinamakan Thiam. Prosesi Thiam dilakukan di Kelenteng ataupun Lithang (tempat ibadah Khonghucu). Semua pemain dan pengurus barongsai diwajibkan untuk mengikuti prosesi Thiam. Meskipun prosesi dilakukan di Kelenteng ataupun Lithang, namun mereka yang tidak menganut agama seperti yang diyakini oleh orang Tionghoa dianjurkan untuk berdoa menurut kepercayaannya masing-masing. Selain digunakan untuk kepentingan ritual, Thiam juga berlaku untuk barongsai atau perangkat barongsai yang masih baru (belum pernah dipakai). Hal ini oleh mereka dipercaya dapat mengusir roh-roh jahat yang ada di dalam barongsai atau perangkat barongsai tersebut, sehingga pertunjukan tidak diganggu oleh roh jahat.

\section{Fungsi Entertainment atau Hiburan}

Pertunjukan barongsai identik dengan hiburan, karena musiknya yang semarak dan gerakan-gerakan penari yang sangat atraktif, walaupun sarat dengan mitos dan spiritual, namun inilah yang menghibur penonton dalam pertunjukannya. Baik digunakan untuk kepentingsan ritual ataupun bukan, pertunjukan barongsai dapat menarik masyarakat sekitar untuk menyaksikannya. Indra pengelihatan kita akan mencari barongsai saat terdengar musik yang di dominasi oleh gendang dan simbal dengan ketukan-ketukan yang khas, sehingga tidak heran bila pertunjukan barongsai di zaman sekarang ini telah berubah fungsi. Dahulu barongsai hanya dipentaskan untuk kebutuhan ritual etnis Tionghoa, tetapi kini barongsai telah bertambah menjadi sarana untuk hiburan.Berbeda dengan acara ritual, dalam fungsi pertunjukan untuk hiburan ini barongsai tidak wajib melakukan Thiam terlebih dahulu sebelum dimainkan. Berbagai acara seperti ulang tahun, pernikahan, pembukaan toko, bahkan kampanye partai politik dapat dimeriahkan oleh pertunjukan barongsai. Meskipun digunakan untuk kepentingan hiburan, namun kepercayaankepercayaan tentang hadirnya kekuatan gaib dalam pertunjukan barongsai pada acara tersebut masih diyakini oleh mereka. Suatu contoh apabila dalam pembukaan suatu toko dimeriahkan oleh pertunjukan barongsai maka ia dipercaya sebagai penolak bala. Segala sesuatu berbau mistik yang akan masuk atau telah ada di dalam akan diusir oleh barongsai melaluipertunjukannya, sebagaimana yang diungkapkan oleh Heri Subianto, yang merupakan pelatih Liong dan barongsai Tripusaka.

“...Peresmian toko supaya tokonya itu tidak ada gangguan yang sifatnya mungkin tidak terlihat. Orang punya gagasan mungkin kalau ada orang yang kurang suka dengan berdirinya toko ini mungkin dari saingannya itu supaya toko itu tidak bisa berkembang karena ada cara-cara mistik. Supaya mistikmistik itu hilang tidak bisa berkembang (ben ora mandi) itu bisanya barongsai itu ditampilkan, untuk menolak supaya hawa jahat atau hawa negatif itu sirna...."(Heri Subianto, 29 Juli 2017)

Selain fungsi pertunjukan sebagai sarana ritual tersebut di atas, terdapat juga orang yang memanggil pertunjukan barongsai hanya untuk memeriahkan acara. Mereka tertarik akan keindahan yang disajikan oleh kesenian ini sebagai sarana hiburan untuk tamu undangan.

\section{Fungsi Olah Raga atau Perlombaan}

Dari sekian banyak anggota kelompok barongsai Tripusaka, sebagian besar mengatakan bahwa ketertarikan mereka dengan kesenian tersebut, adalah karena adanya unsur olahraga yang tentunya berkorelasi langsung dengan kesehatan. 
Unsur olah raga ini dapat mereka nikmati karena menyatu dengan kesenian yang dibangun oleh rasa senang. Walaupun menurut mereka kesenian ini memerlukan keterampilan khusus, sehingga perlu rutinitas dan kesungguhan dalam berlatih. Fungsi olah raga ini mempunyai ketertarikan yang kuat bagi masyarakat non-Tionghoa untuk bergabung dengan kelompok tersebut.

Pertunjukan barongsaijuga diperlombakan selain fungsinya sebagai hiburan, olah raga, dan ritual. Keindahan gerak, kekompakan, dan kreativitas dari masing-masing kelompok yang menjadi dasar diselenggarakannya perlombaan barongsai. Penyelenggaraan dari perlombaan barongsai mulai dari federasi barongsai tingkat lokal, Propinsi, Nasional bahkan tingkat Intemasional. Anggota-anggota yang dipilih untuk mengikuti lomba tersebut diilih berdasarkan pada kemampuan mereka dalam menari, beratraksi, dan kelincahan dalam bergerak. Kriteria ini membuka peluang kepada siapapun untuk dipilih menjadi tim yang akan dikirim untuk mengikuti perlombaan.

Paparan mengenai adaptasi fungsi dari para pemain baik beretnis Tionghoa ataupun nonTionghoa menjadi hal utama agar adanya keberterimaan dalam seni pertunjukan tersebut. Seluruh pemain barongsai harus dapat beradaptasi secara fungsional, agar mereka dapat menempatkan diri secara proporsional. Para pemain juga harus memahami bahwa fungsi ritual adalah core dari fungsi-fungsi lainnya, karena fungsi ritual inilah yang menjadi dasar hadirnya kesenian barongsai dan Liong dalam mitologi dan sejarah masyarakat Cina di tanah leluhurnya, Tiongkok.

\section{SIMPULAN}

Setelah mengkaji dengan cara membangun relasional antar asal-mula munculkan kesenian barongsai, tujuan dan motivasi pemaian untuk bergabung serta, unsur-unsur ektra estetis lainnya dalam seni pertunjukan Barongsai dan Liong, maka dapat disimpulkan. Pertama, bahwa munculnya dan berkembangnya kesenian Barongsai dan Liong di Kota Solo yang berawal sejak tahun 2009 merupakan suatu upaya membangun kembali identitas masyarakat Tionghoa di Surakarta. Karena seperti kita ketahui bahwa politik asimilasi pemerintahan Orde baru cenderung mengekang dan mendiskriminasi kebudayaan dan keyakinan masyarakat Tionghoa. Mereka mencoba untuk membangun model integrasi dalam skala makro yang lebih menghargai dan menghormati keyakinan dan kebudayaan Tionghoa di Surakarta. Hal ini mereka lakukan dengan mengadopasi idiom-idiom budaya-budaya Jawa namun dengan tetap memperkuat pada identitas Tionghoa, seperti Grebeg Sudiro, Imlek, dan perayaan Cap Gomeh.

Kedua, bahwa keterlibatan masyarakat lain (non-Tionghoa) dalam kesenian Barongsai pada awalnya merupakan ketikdaksengajaan atau tanpa disadari (unintentionally). Karena awalnya mereka berkeinginan untuk berlatih seni beladiri wushu, namun karena persoalan fasilitas, kemudian dirumah menjadi kelompok kesenian Barongsai dan Liong. Ketidaksengajaan inilah kemudian yang dimenaje oleh Adji Chandra sehingga menjadi media untuk memberikan pemahaman dan pembelajaran positif kepada peserta non Tionghoa baik terhadap kesenian Barongsai dan Liong ataupun ajaran dan nilai yang dipegang oleh masyarakat Tionghoa. Artinya bahwa tidak ada target-target khusus yang dirumuskan oleh pengelola kelompok kesenian Tripusaka terkait dengan hubungan sosial antara etnis Tionghoa dengan non Tionghoa, yang dilakukan hanyalah memberikan pemahaman mengenai kesenian yang juga terkait dengan religiusitas bagi pemain. Oleh karenanya lingkup keberterimaan ini lebih terfokus pada sesama anggota kelompok barongsai.

Ketiga, keberterimaan antar anggota yang berbeda etnis dan agama di kelompok barongsai, khususnya kelompok Tripusaka, membentuk model akomodasi. Model ini cenderung untuk mengambil unsur-unsur ataupun idiom-idiom kebudayaan lain tanpa harus menghilangkan kebudayaan asalnya. Artinya ada proses dialog baik pada tataran kognitif ataupun praxsis dalam diri individu ataupun kelompok untuk saling menerima dan menggunakan idiom-idiom budaya lain. Cara yang dilakukan adalah dengan melakukan adaptasi yakni dengan melakukan adaptasi sikap dan adaptasi fungsional. Adaptasi sikap terkait dengan adaptasi emotif yakni perubahan pada tataran psikologis terkait dengan rasa benci, tidak suka, emosional yang sangat cepat 
muncul karena perbedaan. Adaptasi emotif ini dilakukan dengan cara lebih mengedepankan rasa senang terhadap kesenian atau memberikan kesadaran-kesadaran estetis kepada semua anggota sehingga rasa yang bersifat engatif dapat berganti dengan hal yang bersifat positif. Adaptasi sikap juga mengedepankan unsur kognitif yakni memberikan pemahaman mengenai barongsai baik pada tataran budaya, filosofis ataupun teologis, sehingga semua peserta dapat memahami hal-hal dasar dari kesenian barongsai dan liong. Adapun adaptasi fungsional, terkait dengan fungsi-fungsi kesenian barongsai yang tidak hanya mempunyai fungsi ritual, namun juga saat ini mempunyai fungsi entertainmen yang lebih mengendepankan hiburan dan fungsi olah raga dan perlombaan yang lebih mengutamakan pada bentuk dan keterampilan permainan barongsai yakni bentuk lantai dan bentuk tonggak.

\section{Daftar Pustaka}

Abdullah, Irwan, 2010. Konstruksi dan Reproduksi Kebudayaan. Cet. IV. Yogyakarta : Pustaka Pelajar

Ali Imron, 2014, Pendidikan Multikultural melalui Reaktualisasi Teater Tradisi di Surakarta dalam Jurnal Manajemen Pendidikan, Vol. 9, No. 1, 10 Januari 2014: P 1 - 14.

Ekstrand, L.H. "Multicultural Education" dalam Saha, Lawrence J. (Eds.). 1997. International Encyclopedia of the Sociology of Education. New York: Pergamon.

Eko Puno Hendro, 2013, Multikulturalisme Sebagai Model Integrasi Etnis Tionghoa Di Indonesia dalam Sabda,Volume 8, Tahun 2013 : 34-42.

Bagus. Haryono, 2011, Estimasi Parameter Integrasi Sosial Suku Tionghoa-Jawa Di Yogyakarta Dan Surakarta: Pengembangan Hybrid Model dalam Jurnal Penelitian dan Evaluasi Pendidikan Tahun 15, Nomor 2, 2011. hlm.287-307.

Diah Ayuk Kusumaningtyas, 2009, Peran Seni Pertunjukan Barongsai Dalam Pengembangan Wisata Budaya Di Kota Surakarta. Laporan Tugas Akhir fak. Seni rupa dan desain, UNS. Tidak diterbitkan.
Djakob Soemardjo, 1992, Perkembangan teater modern dan sastra drama Indonesia, Bandung, Citra Aditya Bhakti.

Garcia, Ricardo L. 1992. Teaching in a Pluralistic Society: Consepts, Models, Strategies. New York: Harper \& Row Publisher.

Geertz, Cliford, 1993, Abangan Santri Priyai dalam masayrakat Jawa, Jakarta, Pustaka Jaya.

Holt, Clair, 2000, Melacak Jejak-Jejak perkembangan Seni Di Indonesia, Bandung, Arti.line dan Masyarakat Seni pertunjukan Indonesia.

Kayam, Umar. 1998. Seni, Tradisi, Masyarakat. Jakarta: Sinar Harapan

Leo Suryadinata, 1990, Mencari Identitas Nasional: Dari Tjoen Bou San sampai Yap Thiam Hien, Jakarta, LP3ES.

I Wayan Wesna Astara, 2011, Multikulturalisme Kesenian Barongsai di Desa adat Kuta dalam Jurnal Mudra, Volume 26, Nomor 1, ISSN 0854-3461, p 41-52.

Nur Sahid, 2000, Interkulturalisme dalam Teater, Shahab Y,Z. 1999, Alih Fungsi Seni dalam Masyarakat Kompleks: Kasus Liang Liong dan Barongsai, dalam jurnal Antropologi Indonesia $24(61): 37-46$ 2004, Seni sebagai Ekspresi Eksistensi Tantangan Kebijakan

Sudono, Suhartono, GR Lono Lastoro Simatupang, 2013, Pertunjukan Liong dan Barongsai di Yogyakarta:Redefinisi Identitas Tionghoa dalam Jurnal Seni \& Budaya Panggung Vol. 23, No. 2, Juni 2013: 109-240. 